Original Russian Text (C) 2019 R.Kh. Pshegusov, F.A. Tembotova, Yu.M. Sablirova, published in Forest Science Issues Vol. 2, No. 3, pp. 1-11

DOI 10.31509/2658-607x-2020-3-1-1-7

\title{
MAIN PATTERNS OF THE SPATIAL LOCALIZATION OF VARIOUS TYPES OF CONIFEROUS AND CONIFEROUS-DECIDUOUS FORESTS OF THE NORTHERN MACROSLOPE OF THE WESTERN CAUCASUS BASED ON EARTH REMOTE SENSING
}

\author{
R.Kh. Pshegusov*, F.A. Tembotova, Yu.M. Sablirova \\ Tembotov Institute of Ecology of Mountain Territories of the RAS \\ I. Armand st. 37a, Nalchik, KBR, 360051, Russia \\ *E-mail: p_rustem@inbox.ru \\ Received 10 June 2019
}

The paper presents a comparative analysis of spatial localization parameters of coniferous and coniferous-deciduous forests in various landscape and climatic conditions of the Western Caucasus. During the study, we set the task of determining parametric variables that would reflect the most significant factors of distribution of coniferous and coniferous-deciduous forests of the Western Caucasus based on the synthesis of field and remote data. In 2016-2018, 76 trial plots for research and material collection were laid in the Western Caucasus. The research resulted in presentation of a typological scheme of coniferous and coniferous-deciduous forests of the research area, and identification of 13 types of forests, that are distributed into 7 groups. The forest stands in the studied forest types are mainly of different ages, multi-storeyed, highly closed, of medium or high density. Conclusions are made about the high accuracy of the spatial distribution model based on the parametric values of discriminant functions and average values of predictors.

Key words: Western Caucasus, coniferous forests, remote sensing data, spatial analysis

One of the issues in the research of the forest ecosystems of the Northwestern Caucasus is the lack of up-to-date mapping of coniferous and coniferous-deciduous forests throughout the North Caucasus (Tembotova et al., 2012; Komarova, 2017) in general and in the Western Caucasus in particular. Identification of the typical features of spatial distribution of plant communities is relevant both from the practical of view (for monitoring and preserving biodiversity at all levels, planning economic activities, etc.) and the theoretical points of view (for establishing ecological parameters of species distribution and patterns of plant community's formation).

For this study, the following objective was set: to identify the parametric variables that reflect the most significant factors of coniferous and coniferous-deciduous forests distribution of the Western Caucasus based on combined field and remote data.

\section{MATERIAL AND METHODS}

The material was collected during expeditions and at the permanent monitoring sites in the northern part of the Shaposhnikov Caucasian state natural biosphere reserve (hereinafter the Caucasian nature reserve). Geobotanical descriptions were made and taxational characteristics of the stands were determined on the forest areas in the valley of the Malaya Laba river and its tributaries. Traditional geobotanics research methods and standards adopted in forest taxation were used in field research (Sukachev, 1961; 1972; Zagreev et al., 1992; Neronov, 2002). The Dominant species approach was the basis for forest cover classification in view of 
geobotanical descriptions results. In this paper, forest type of forest was understood as a type of biogeocenosis (Sukachev, 1964).

The size of the trial plot was $900 \mathrm{~m}^{2}$, which is generally equivalent to the standard pixel of Landsat multispectral survey. 78 trial plots in total were surveyed in the Western Caucasus in 2012-2015 and 2017-2018.

The scenes of average spatial resolution Landsat 8 OLI/TRS dated September 13, 2018 (scene ID: LC81730302018256LGN00) were used to assess the parameters of the current spatial localization, as it was the closest to the research period, and not covered with clouds. Regression and discriminant analyses and models of regression/classification trees (Puzachenko, 2004) were used for spatial analysis and test data interpolation. Further forest type classification and modelling, was performed through discriminant analysis at the estimated probability of occurrence (is based on the frequency of the forest types occurrence in the training sample) with the reverse step-by-step inclusion of variables at the level of F-test $=$ 1. On the whole, high recognition accuracy (on average $95.5 \%$ ), the regression coefficient values, and results of creating classification trees are the evidence of high predictive capability of both the training sample and the created interpolation model. Respective literature gives more detailed description of the research methods (Bartalev, 2006; Kozlov et al., 2008; Isaev, Chernen'kova, 2009; Tembotova, Pshegusov, Tlupova, 2012).

\section{RESULTS AND DISCUSSION}

As a result of regression analysis of 86 remote sensing variables (Wood, 1996; Sandlerskij, 2013; Fick, Hijmans, 2017; McNally et al., 2017), which together characterize the vegetation and thermodynamic components and the morphometric characteristics of the terrain, 18 turned out to be significant (Table 1). High regression coefficients $\left(\mathrm{R}=0.73 ; \mathrm{R}^{2}=0.7114\right.$; accumulated $\mathrm{R}^{2}=0.7144$; $\left.\mathrm{F}(19.43)=2929.4\right)$ should also be highlighted, as they indicate high predictive capability of these variables at modelling the spatial distribution of coniferous and coniferous-deciduous forests in the study area.
To make primary classification, we have constructed general classification and regression trees (GC\&RT). The results of displaying of the importance of variables in the classification analysis (Fig. 1) in general are in line with those in the regression analysis, but here terrain parameters (altitude and slope direction), and vegetation indices (among spectral variables) turned out to be significant.

According to the results of forest plot surveys on the territory of the eastern part of the Caucasian reserve, 13 forest types were identified, which were further distributed in 7 groups. The group of mixed-grass fir forests includes oxalis beech-fir forest, bonitet class II, dead-soil beech-fir forest, bonitet class II, and impatiens beech-fir forest, bonitet class II. The stand body of this group is dominated by Abies nordmanniana (Steven.) Spach. and Fagus orientalis Lipsky. The crown closure in different areas ranges between 0.8-0.9. The undergrowth is represented by singlular plants of Sambucus nigra L. and Corylus avellana L. The total projective cover (TPC) of the ground cover is $50-60 \%$, with the exception of the beech-fir dead-soil forest, where the grassy layer is nearly absent.

In the group of fern fir forests, fern fir forest of bonitet class II may be distinguished. The stand is dominated by Abies nordmanniana (Steven.) Spach, whereas in the second tier, Fagus orientalis Lipsky, Tilia begoniifolia Steven, Acer platanoides L., and Picea orientalis (L.) Link. can be found in small amounts. Crown closure is 0.8. The undergrowth is as good as absent. The ground cover TPC is $20-30 \%$.

In the group of mixed-grass beech forests, one type of forest is identified, i.e. oxalis spruce-beech forest, bonitet class I. The stand is dominated by Fagus orientalis Lipsky and Picea orientalis (L.) Link. Tree canopy closure is 0.8 . The undergrowth is absent. The ground cover TPC is $15-20 \%$.

The group of fern beech forests includes fern spruce-beech forest, bonitet class I, and fern fir-beech forest, bonitet class II. Forest areas of a number of forest types are dominated by Fagus orientalis Lipsky and Picea orientalis (L.) Link. There also are individual plants of Acer platanoides L., 
Alnus incana (L.) Moench, A. glutinosa (L.) Gaertn, and Abies nordmanniana (Steven.) Spach. Crown closure is 0.8. The undergrowth is nearly absent. The ground cover TPC in different areas ranges between $20-60 \%$.

Table 1. Regression analysis results

\begin{tabular}{|l|c|c|c|c|c|c|}
\hline \multicolumn{7}{|c|}{ Regression Summary: } \\
\hline & R $=0.73832891 ; R^{2}=0.711446645 ;$ & Adjusted R $=0.71442738 ;$ F $(19,430588)=2929.4$ \\
\hline Intercept & - & Std.Err. - of b* & b & Std.Err. - of b & z & $\begin{array}{c}\text { p- } \\
\text { value }\end{array}$ \\
\hline SLOPE & -0.297 & - & 9.684 & 3.243 & 2.986 & 0.003 \\
\hline NDVI & -0.173 & 0.014 & -7.152 & 0.578 & -12.379 & 0.000 \\
\hline NDWI & 0.218 & 0.034 & 6.579 & 1.028 & 6.398 & 0.000 \\
\hline K & -0.271 & 0.020 & -10.730 & 0.786 & -13.653 & 0.000 \\
\hline TVI & -0.121 & 0.038 & -0.084 & 0.026 & -3.236 & 0.001 \\
\hline RVI & 0.182 & 0.021 & 0.454 & 0.051 & 8.855 & 0.000 \\
\hline TK & -0.030 & 0.002 & -0.015 & 0.001 & -19.193 & 0.000 \\
\hline SWIR2_R & -0.045 & 0.014 & -0.612 & 0.191 & -3.210 & 0.001 \\
\hline G_B & 0.122 & 0.010 & 10.789 & 0.928 & 11.630 & 0.000 \\
\hline DU & -0.243 & 0.012 & -0.043 & 0.002 & -20.141 & 0.000 \\
\hline REL & -0.025 & 0.002 & 0.000 & 0.000 & -12.496 & 0.000 \\
\hline LMI & 0.219 & 0.013 & 5.267 & 0.323 & 16.326 & 0.000 \\
\hline R_G & 0.100 & 0.011 & 4.809 & 0.532 & 9.037 & 0.000 \\
\hline TSAVI & 0.377 & 0.047 & 10.953 & 1.378 & 7.948 & 0.000 \\
\hline ASPECT & -0.010 & 0.002 & 0.000 & 0.000 & -6.632 & 0.000 \\
\hline VI7 & 0.020 & 0.007 & 1.255 & 0.470 & 2.669 & 0.008 \\
\hline W & 0.117 & 0.013 & 0.041 & 0.005 & 8.825 & 0.000 \\
\hline BR & 0.110 & 0.016 & 0.016 & 0.002 & 7.020 & 0.000 \\
\hline
\end{tabular}

Note: SLOPE - slope, degrees; NDVI - normalized difference vegetation index; NDWI normalized difference water index in green phytomass; $\mathrm{K}$ - Kullback entropy (a measure of structural complexity of a system that reflects (Eout) and absorbs (R) energy); TVI - transformed vegetation index; RVI - Ratio vegetation index; TK -surface temperature, Kelvin; SWIR2_R short-wave index of the red spectrum; G_B - photosynthetic rate, transpiration; DU - increase in internal energy of the system; REL - altitude above sea level, m; LMI - moisture content in the green phytomass; R_G - photosynthetic rate, net production; TSAVI - transformed soil adjusted vegetation index; ASPECT - slope exposition, degrees; VI7 - infrared vegetation index; W - water content in green phytomass (Kauth's Tasseled Cap transformation); BR - brightness, albedo (Kauth's Tasseled Cap transformation). 


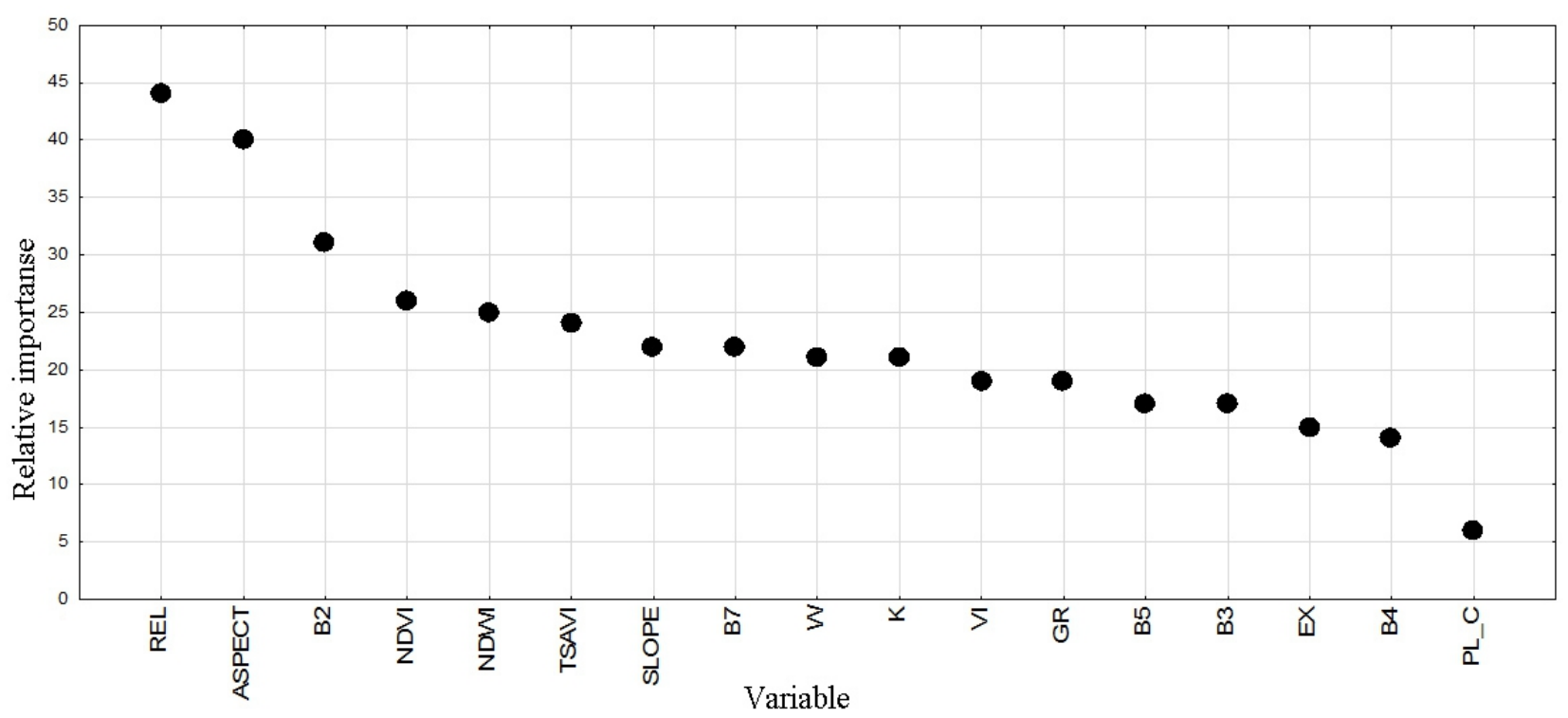

Figure 1. Variable importance plot to the construction of the forest type classification tree model

The group of fern spruce forests is represented by fern beech-spruce forest, bonitet class II. Picea orientalis (L.) Link and Fagus orientalis Lipsky are predominant in forests of this type. Alnus incana (L.) Moench, Abies nordmanniana (Steven.) Spach, Carpinus betulus L., and Acer platanoides L. are found only sporadically. Tree canopy closure is 0.9 . The undergrowth is not developed. The ground cover TPC is $30 \%$.

The group of mixed-grass spruce forests is represented by dead-soil beech-spruce forest, bonitet class II. The tree tier consists of Fagus orientalis Lipsky and Picea orientalis (L.) Link. Crown closure is 0.9. Grossularia uvacrispa (L.) Mill., Ribes aureum Pursh, and Euonymus europaeus L. were documented as part of the undergrowth. The ground cover TPC is $0-10 \%$.

The group of multi-storeyed pine forests includes the following forest types: mixedgrass oak-pine, azalea oak-pine, mixed-grass hornbeam-pine, and mixed-grass aspen-pine forests. The tree layer is formed by Pinus sylvestrus L., in different parts it is also dominated by Quercus robur L., Carpinus betulus L., and Populus tremula L. Crown closure is $0.5-0.6$. The undergrowth is formed by Prunus spinosa L, Spiraea hypericifolia L, Rhododendron luteum Sweet., Corylus avellana L., Ribes aureum Pursh, and Sambucus nigra L. The ground cover TPC in different types of forest ranges between 5$80 \%$.

K.Yu. Golgofskaya (1967) developed a fractional classification scheme of forest typology for the Caucasian reserve; the scheme includes, in particular, 24 forest types where coniferous species dominate the stands. The author identified the following groups: stony beech-fir forests, Colchian-shrub fir forests, medium-grass fescue fir forests, reedgrass fir forests, cliff fir forests, sabershaped beech fir forests, mixed deciduous fir forests, stony spruce forests, moss spruce forests, medium-grass fescue spruce forests, reedgrass pine forests, grass pine forests, azalea pine forests, and mixed-grass pine forests, which were not found within the territory of the eastern part of the Caucasian reserve. However, for the study area, the classification scheme includes the groups of mixed-grass spruce forests and fern spruce forests, as well as the group of multi-storeyed pine forests including mixed-grass oak-pine, azalea oak-pine, mixed-grass hornbeam-pine, and mixed-grass aspen-pine forest types, which are not reported in previous studies on the territory of the Caucasian reserve. In his work, S. M. Bebia (2002) gives a detailed classification typological scheme of the Caucasus fir forests. The author identifies the groups of mixed-grass fir and fern fir forests, which we also found on the territory of the study area. S. M. Bebia also identifies groups 
of fescue fir forests, fir forests with Colchian undergrowth, and mixed-grass subalpine fir forests, which we could not identify on the territory of the Malaya Laba river basin. According to our research, the following forest types with the participation of the Nordmann fir were identified on the territory of the eastern part of the reserve: oxalis beech-fir, dead-soil beech-fir, impatiens beech-fir, fern fir-beech, and fern fir forest types.

The spatial parameters for the identified forest type groups and specifically forest types are distributed as follows.

The group of mixed-grass fir forests.

Oxalis beech-fir bonitet class II forest occupies the largest area (7.604 ha, 19.6\% of the forested area) of all the identified groups of forests; it is common at altitudes ranging from 600 to $2,200 \mathrm{~m}$ above sea level on the slopes of moderate steepness $\left(15-20^{\circ}\right)$ with the northern and north-western slope direction.

dead-soil beech-fir bonitet class II forest occupies an area of about 350 hectares on the slopes of moderate steepness $\left(20-27^{\circ}\right)$ with the eastern and south-eastern direction.

Impatiens beech-fir bonitet class II forest occupies an area of about 200 hectares with the southern and south-eastern slopes of moderate steepness $\left(16-21^{\circ}\right)$.

The group of fern fir forests. In this group, one forest type was identified in the study area, i.e. the fern fir bonitet class II forest which occupies about $12.5 \%$ of the forested area and can be found on steep slopes (about $30^{\circ}$ ) with the north-western direction.

The group of mixed-grass beech forests. In this group, one forest type was identified in the study area, i.e. the oxalis spruce-beech bonitet class I forest which occupies about 5 thousand hectares $(13 \%)$ on gentle and moderately steep west-facing slopes $\left(8-17^{\circ}\right)$.

The group of fern beech forests. This is a group of forest types that is very common in the Western Caucasus, and, along with the group of mixed-grass fir forests, it is the most represented group in terms of the occupied area (about $30 \%$ of the forested area).

The spruce-beech fern bonitet class I forest occupies about 6 thousand hectares $(16 \%)$ on flattened west and north-west-facing slopes ( $5^{\circ}$ on average).

The fern fir-beech bonitet class II forest occupies 5.100 hectares $(13 \%)$ on gentle west and south-west-facing slopes $\left(10^{\circ}\right)$.

The group of fern spruce forests. This group is represented by one forest type, i.e. the fern beech-spruce bonitet class II forest which occupies an area of 2.9 thousand hectares $(7.5 \%)$ on gentle south-facing slopes $\left(9.8^{\circ}\right)$.

The group of mixed-grass spruce forests is also represented by one forest type, i.e. the dead-soil beech-spruce bonitet class II forest which occupies a small area of 179 hectares $(0.46 \%)$ on the gentle south-east-facing slopes.

The group of multi-storeyed pine forests is represented by the following forest types:

the mixed-grass oak-pine forest occupies an area of 643 hectares $(1.66 \%)$ on the southsouth-east-facing slopes of moderate steepness $\left(22^{\circ}\right)$;

the azalea oak-pine forest occupies 339 ha $(0.87 \%)$ on the slopes of moderate steepness $\left(28^{\circ}\right)$ with the southern direction.

The mixed-grass hornbeam-pine forest occupies about 3 thousand hectares $(7.8 \%)$ on the slopes of moderate steepness $\left(17.5^{\circ}\right)$ with the eastern and south-eastern direction.

The mixed-grass aspen-pine forest occupies an area of 2.2 thousand hectares $(5.85 \%)$ on the south-south-east-facing slopes of moderate steepness $\left(18^{\circ}\right)$.

The largest area among the identified forest types in this model is occupied by the oxalis beech-fir forest type, the least represented are the dead-soil (beech-spruce and beech-fir) types (Table 2). 
Table 2. Areas of the main types of coniferous and coniferous-deciduous forests of the Caucasian

\begin{tabular}{|c|l|c|c|c|}
\hline \multirow{2}{*}{ No. Forest type } & \multicolumn{2}{c}{ Area } & reserve \\
\cline { 3 - 5 } & & pixel & ha & \\
\cline { 3 - 5 } 1 & Dead-soil beech-spruce bonitet class II forest & 1.992 & 179.28 & 0.46 \\
\hline 2 & Fern beech-spruce bonitet class II forest & 32.098 & 2.888 .82 & 7.45 \\
\hline 3 & Oxalis beech-fir bonitet class II forest & 84.496 & 7.604 .64 & 19.62 \\
\hline 4 & Dead-soil beech-fir bonitet class II forest & 3.882 & 349.38 & 0.90 \\
\hline 5 & Impatiens beech-fir bonitet class II forest & 2.244 & 201.96 & 0.52 \\
\hline 6 & Mixed-grass hornbeam-pine forest & 33.927 & 3.053 .43 & 7.88 \\
\hline 7 & Azalea oak-pine forest & 3.765 & 338.85 & 0.87 \\
\hline 8 & Mixed-grass oak-pine forest & 7.153 & 643.77 & 1.66 \\
\hline 9 & Fern spruce-beech bonitet class I forest & 69.091 & 6.218 .19 & 16.05 \\
\hline 10 & Oxalis spruce-beech bonitet class I forest & 55.936 & 5.034 .24 & 12.99 \\
\hline 11 & Mixed-grass aspen-pine forest & 25.201 & 2.268 .09 & 5.85 \\
\hline 12 & Fern fir bonitet class II forest & 5.145 & 4.873 .05 & 12.57 \\
\hline 13 & Fern fir-beech bonitet class II forest & 56.673 & 5.100 .57 & 13.16 \\
\hline \multicolumn{2}{|c|}{ Total } & 430.603 & 38.754 & 100 \\
\hline
\end{tabular}

\section{CONCLUSION}

Thus, according to the results of field work on the territory of the eastern part of the Caucasian reserve, 13 types of forest were identified and further distributed into 7 groups of forest types: fern spruce forests, mixedgrass spruce forests, fern beech forests, mixed-grass beech forests, fern fir forests, mixed-grass fir forests, and multi-storeyed pine forests. The forest stands in the studied forest types are mainly of different ages, multi-storeyed, highly closed, of medium or high density.

According to the developed model, the area of forests dominated by coniferous species in the research area is 38.8 thousand ha $(14 \%$ of the study area). They are mainly

\section{REFERENCES}

Bartalev S.S., Razrabotka metodiki regional'noj jekologicheskoj ocenki sostojanija lesov po dannym sputnikovyh nabljudenij Avtoref. diss. ... kand. tehn. nauk (Development of a methodology for regional environmental assessment of forest condition based on satellite observations. Candidate's biol. sci. thesis), Moscow, 2006. $21 \mathrm{p}$.

Bebija S.M., Pihtovye lesa Kavkaza (Caucasus fir forests), Moscow, Izd-vo MGUL, 2002, $237 \mathrm{p}$. confined to the steep $\left(25-30^{\circ}\right.$ or more) northern and western slopes $(60-70 \%$ of the area of the slopes of these directions), with altitudes ranging from 1.000 to $2.000 \mathrm{~m}$ above sea level.

In the future, the classification typological scheme of coniferous and coniferousdeciduous forests of the Western Caucasus will be expanded and specified. Also, the obtained parametric values of the discriminant functions and the average values of predictors allow using them in the future when recognizing and classifying forest types from the previous period images to develop a model of the spatial and temporal dynamics of the Western Caucasus forests.

Fick S.E., Hijmans R.J., Worldclim 2: New 1$\mathrm{km}$ spatial resolution climate surfaces for global land areas, International Journal of Climatology, 2017, No. 37, pp. 4302-4315.

Golgofskaya K.Yu., Tipy bukovyh i pihtovyh lesov bassejna r. Beloj i ih klassifikacija (Types of beech and fir forests of the Belaya river basin and their classification), Trudy Kavkazskogo gosudarstvennogo zapovednika, 1967, No. 9, pp. 157-284. 
Isaev A.S., Chernen'kova T.V., Monitoring bioraznoobrazija lesov: podhody i rezul'taty (Forest biodiversity monitoring: approaches and results), Lesnye resursy taezhnoj zony Rossii: problemy lesopol'zovanija $i$ lesovosstanovlenija (Forest Resources of the Taiga Zone of Russia: Problems of Forest Management and Reforestation), Petrozavodsk, September 30 - October 03 2009, Petrozavodsk: KarNC RAN, 2009, pp. 6062.

Komarova A.F., Raznoobrazie temnohvojnyh lesov Severo-zapadnogo Kavkaza $i$ zakonomernosti ih prostranstvennogo raspredelenija, Diss. ... kand. biol. nauk (Diversity of dark coniferous forests of the North-Western Caucasus and pattern of their spatial distribution), Moscow, 2017, $174 \mathrm{p}$.

Kozlov D.N., Puzachenko M.Ju., Fedjaeva M.V., Puzachenko Ju.G., Otobrazhenie prostranstvennogo var'irovanija svojstv landshaftnogo pokrova na osnove distancionnoj informacii i cifrovoj modeli rel'efa (Mapping of spatial variation of landscape cover properties based on distance information and digital elevation model), Izvestija RAN. Serija geograficheskaja. 2008. No. 4. pp. 112124.

McNally A., Arsenault K., Kumar S., Shukla S., Peterson P., Wang S., Funk C., PetersLidard C.D., Verdin J.P., A land data assimilation system for sub-Saharan Africa food and water security applications, Scientific Data, 2017, No. 4, p. 170012.

Neronov V.V., Polevaja praktika po geobotanike $v$ srednej polose evropejskoj Rossii: Metodicheskoe posobie (Field practice in geobotany in Central European Russia: Methodical manual), Moscow: Izd-vo Centra ohrany dikoj prirody, 2002, $139 \mathrm{p}$.

Puzachenko Ju.G., Matematicheskie metody $v$ jekologicheskih $i$ geograficheskih issledovanijah (Mathematical methods in environmental and geographical research), Moscow: Akademija, 2004, 408 p.

Sandlerskij R.B., Termodinamicheskie harakteristiki juzhno-taezhnyh biogeocenozov na osnove distancionnoj informacii (jug Valdajskoj vozvyshennosti, Central'no-Lesnoj zapovednik) Avtoref. diss. ... kand. biol. nauk. (Thermodynamic characteristics of southern taiga biogeocenoses based on remote information (south of Valdai Upland, Central Forest Reserve), Moscow, 2013. $26 \mathrm{p}$.

Sukachev V.N. Dinamika lesnyh biogeocenozov, In: Osnovi lesnoi biogeocenologii, Moscow, 1964, pp. 458486.

Sukachev V.N., Izbrannye trudy. Osnovy lesnoj tipologii $i$ biogeocenologii (Selected Works. Basics of forest typology and biogeocenology), Leningrad: Nauka, 1972, $418 \mathrm{p}$.

Sukachev V.N., Zonn S.V., Metodicheskie ukazanija $k$ izucheniju tipov lesa (Guidelines for the study of forest types), Moscow: Izd-vo AN SSSR, 1961, 144 p.

Tembotova F.A., Pshegusov R.H., Tlupova Ju.M., Lesa severnogo makrosklona Central'nogo Kavkaza (jel'brusskij i terskij varianty pojasnosti) (Forests of the northern macroslope of the Central Caucasus (Elbrus and Terek variants of zonality)), In: Raznoobrazie $i$ dinamika lesnyh jekosistem Rossii (Diversity and dynamics of forest ecosystems of Russia), Moscow: KMK, 2012, pp. 227-251.

Wood J., The Geomorphological Characterization of Digital Elevation Models. Ph.D. thesis, Leicester: University of Leicester, 1996.

Zagreev V.V., Suhih V.I., Shvidenko A.Z., Gusev N.N., Moshkalev A.G., Obshhesojuznye normativy dlja taksacii lesov: Spravochnik (All-Union regulations for forest taxation: a Handbook), Moscow: Kolos, 1992. 495 p.

Reviewer: $\mathrm{PhD}$ in biology, senior researcher N.E. Shevchenko 